\title{
Endoscopic Palliation of Hilar Cholangiocarcinoma: Usefulness of Selective Occlusion of One Intrahepatic Duct
}

\author{
João Fernandes ${ }^{\mathrm{a}, \mathrm{b}}$ Tarcísio Araújo $^{\mathrm{a}}$ Jorge Canena ${ }^{\mathrm{c}}$ Luís Lopes $^{\mathrm{a}, \mathrm{d}, \mathrm{e}}$ \\ ${ }^{a}$ Gastroenterology Department, Hospital Santa Luzia, Viana do Castelo, Portugal; ' Gastroenterology Department, \\ Centro Hospitalar Cova da Beira EPE, Covilhã, Portugal; ' Nova Medical School/FCML, Universidade Nova de Lisboa,

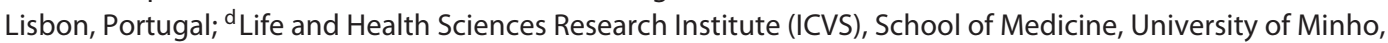

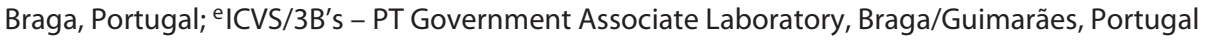

Keywords

Hilar cholangiocarcinoma - Endoscopic retrograde cholangiopancreatography - Malignant biliary stenosis .

Palliative biliary drainage

\section{Paliação Endoscópica do Colangiocarcinoma Hilar: Utilidade da Oclusão Seletiva de Um Ducto Intrahepático}

\section{Palavras Chave \\ Colangiocarcinoma hilar · CPRE - Estenose biliar maligna . Drenagem biliar paliativa}

Endoscopic retrograde cholangiopancreatography with stent placement for palliative biliary drainage is a common strategy used in the management of patients with unresectable hilar cholangiocarcinomas $[1,2]$.

Selective placement of two guidewires, one in the right intrahepatic duct (RIHD) and the other in the left hepatic duct (LIHD), is an essential prerequisite for bilateral stenting. However, the insertion of the second guidewire to the contralateral intrahepatic duct can be extremely difficult in some patients, even after using multiple ma-

\section{KARGER}

E-Mail karger@karger.com www.karger.com/pjg (c) 2019 Sociedade Portuguesa de Gastrenterologia Published by S. Karger AG, Basel

Karger

Open access

This article is licensed under the Creative Commons AttributionNonCommercial-NoDerivatives 4.0 International License (CC BYNC-ND) (http://www.karger.com/Services/OpenAccessLicense) Usage and distribution for commercial purposes as well as any distribution of modified material requires written permission. neuvers, using different types of catheters and guidewires $[3,4]$.

In this video (online suppl. Video 1; see www. karger.com/doi/10.1159/000500145 for all online suppl. material), we demonstrate a technique to overcome the inability to direct the second guidewire to the contralateral intrahepatic duct. We describe an 85-year-old man, with a type II hilar cholangiocarcinoma, referred to our department for palliative bilateral stenting. After swiftly passing the first guidewire to the right lobe, we faced unexpected difficulties in directing the second guidewire to the dilated LIHD. Several maneuvers were attempted, including the use of angled-tip and small caliber hydrophilic wires, but all resulted invariably in the cannulation of the right system. In order to overcome this difficulty, we introduced a $15-\mathrm{mm}$ retrieval balloon into the dilated RIHD; the balloon was inflated immediately proximal to the hepatic bifurcation, blocking the access to the RIHD. Subsequently, a second guidewire was inserted alongside the balloon catheter, across the hilar stricture and easily deflected off the inflated balloon into the LIHD (Fig. 1). Two self-expandable metal stents were successfully deployed (Fig. 2, 3).

To the best of our knowledge, there are no multimedia reports on this technical tip to facilitate the passage of a 


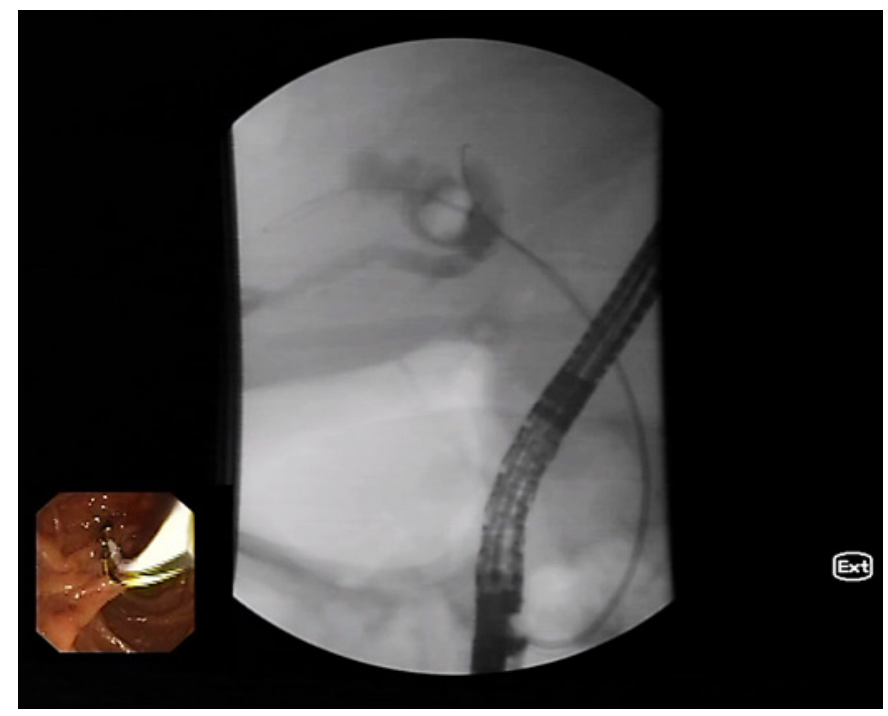

Fig. 1. Fluoroscopy image showing the retrieval balloon occluding the RIHD in order to deflect the second guidewire into the LIHD.

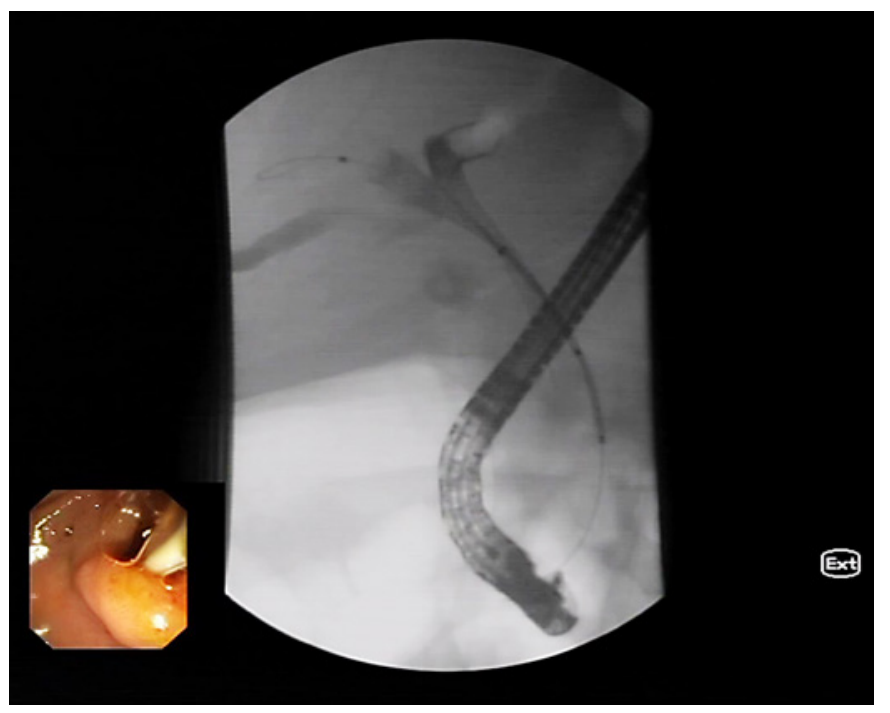

Fig. 2. Fluoroscopy image showing deployment of two parallel selfexpandable metal stents.
Fig. 3. X-ray image showing the placement of both guidewires and the deployment of both self-expandable metal stents.

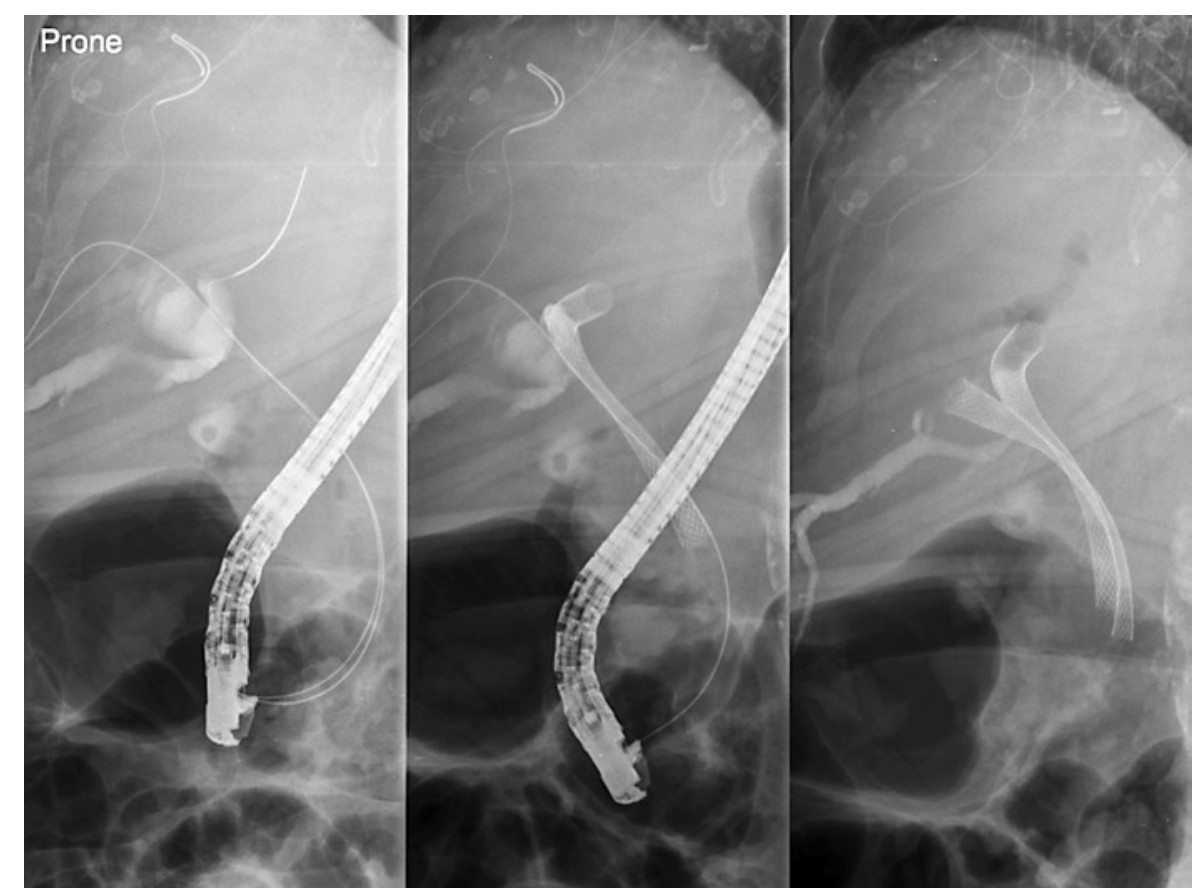

second guidewire to the opposite intrahepatic duct, which was first reported by Husain et al. [5]. The use of this technical maneuver could be a very useful tool for increasing the success of bilateral stenting in patients with hilar cholangiocarcinoma.

\section{Statement of Ethics}

This study did not require informed consent nor review/approval by the appropriate ethics committee. 
Disclosure Statement

The authors declare no conflict of interest.

\section{Author Contributions}

J.F. and L.L. wrote the manuscript. T.A. and J.C. were responsible for the revision of its contents.
References

Endoscopic Palliation of Hilar Cholangiocarcinoma
1 Dumonceau JM, Tringali A, Blero D, Devière J, Laugiers R, Heresbach D, et al.; European Society of Gastrointestinal Endoscopy. Biliary stenting: indications, choice of stents and results: European Society of Gastrointestinal Endoscopy (ESGE) clinical guideline. Endoscopy. 2012 Mar;44(3):277-98.

2 Larghi A, Tringali A, Lecca PG, Giordano M, Costamagna G. Management of hilar biliary strictures. Am J Gastroenterol. 2008 Feb; 103(2):458-73.
3 Kim JY, Kang DH, Choi CW, Kim HW, Park SB, Kim DU. Selective intrahepatic duct cannulation by using a triple-lumen catheter for endoscopic bilateral stenting in hilar cholangiocarcinoma. Gastrointest Endosc. 2010 Jul; 72(1):192-8.

4 Gulati A, Thakkar P, Thakkar S. Endoscopic management of hilar stricture. Tech Gastrointest Endosc. 2016;18(2):67-74.

5 Husain A, Debold C, Edmundowicz SA, Jonnalagadda SS. Directed balloon-assisted guidewire access into intrahepatic ducts. Gastrointest Endosc. 2001 Jul;54(1):118-9. 